\title{
Problem to Auto Stop
}

National Cancer Institute

\section{Source}

National Cancer Institute. Problem to Auto Stop. NCI Thesaurus. Code C139511.

An auto stop function of a device did not operate correctly. 